Technical Note

\title{
Alum application to improve water quality in a municipal wastewater treatment wetland: Effects on macrophyte growth and nutrient uptake
}

\author{
Lynette M. Malecki-Brown $^{\mathrm{a}}$, John R. White ${ }^{\mathrm{b}, *}$, Hans Brix ${ }^{\mathrm{c}}$ \\ ${ }^{a}$ Soil E Water Science, University of Florida, Gainesville, FL 32611, USA \\ ${ }^{\mathrm{b}}$ Wetland and Aquatic Biogeochemistry Lab., Department of Oceanography E' Coastal Sciences, School of the Coast E' Environment, \\ Louisiana State University, Baton Rouge, LA 70803, USA \\ ${ }^{\mathrm{c}}$ Department of Biological Sciences, Aarhus University, Dk-8000 Århus, Denmark
}

\section{A R T I C L E I N F O}

\section{Article history:}

Received 20 May 2009

Received in revised form 1 February 2010

Accepted 2 February 2010

Available online 24 February 2010

\section{Keywords:}

Aluminum

Constructed wetland

Najas

Phosphorus

Schoenoplectus

Typha

\begin{abstract}
A B S T R A C T
Application of low doses of alum to treatment wetlands to reduce elevated outflow winter phosphorus concentrations were tested in mesocosms vegetated with either Typha domingensis, Schoenoplectus californicus, or submerged aquatic vegetation (SAV) (Najas guadalupensis-dominated). Alum was pumped to experimental units at a rate of $0.91 \mathrm{~g} \mathrm{Al} \mathrm{m}^{-2} \mathrm{~d}^{-1}$ and water quality monitored for 3 months. The alum application significantly improved the outflow water quality and overall the growth of the plants was unaffected by the alum application. Biomass and growth varied between species and through time, but no significant effects of alum application were detected. The concentrations of nutrients and mineral elements in the aboveground tissues differed between species and over time, but only the concentration of $\mathrm{Al}$ in plant tissue was increased by alum additions. The concentration of $\mathrm{Al}$ was 50 -fold higher in alumtreated SAV as compared to the control, and in Typha and Schoenoplectus the concentrations were 4- and 2 -fold, higher, respectively. The N/P ratios in the plant tissues were low $(<10)$ suggesting that their growth and biomass was limited by nitrogen. The research suggests that a continuous or seasonal low-dosage alum application to treatment wetlands provides an effective tool to maintain discharge concentrations within permitted values during the inefficient winter treatment times. We suggest that the use of alum should be restricted to treatment wetland areas dominated by emergent vegetation as the effects of the elevated Al concentrations in SAV needs further study.
\end{abstract}

(c) 2010 Elsevier Ltd. All rights reserved.

\section{Introduction}

Nutrient and contaminants are removed in treatment wetlands through a number of abiotic and biotic removal mechanisms such as physical settlement, plant and microbial uptake, sorption and denitrification in the case of nitrogen (Brix, 1997; White and Reddy, 1999, 2000; Conkle et al., 2008). In wetland systems that have been operated for decades, treatment effectiveness has been found to decline and few methods are available to restore the treatment capacity including soil removal (Wang et al., 2006) and prescribed burns (White et al., 2008). There is also decreased efficiency of nutrient removal during the winter months as biological activity decreases or from an increase in nutrient loading, due to additionally permitted wastewater, which calls for new or improved wetland management tools to maintain water quality within acceptable limits. One possible option involves the inactivation of nutrients through the use of chemical amendments (MaleckiBrown et al., 2007).

\footnotetext{
* Corresponding author. Tel.: +1 225578 8792; fax: +1 2255786423 .

E-mail address: jrwhite@lsu.edu (J.R. White).
}

While alum $\left(\mathrm{Al}_{2}\left(\mathrm{SO}_{4}\right)_{3} \cdot 14 \mathrm{H}_{2} \mathrm{O}\right)$ has been used for $\mathrm{P}$ inactivation in lakes and for P removal in wastewater treatment plants for decades (Welch and Schrieve, 1994; Berkowitz et al., 2006), there has been little research done until recently on its potential effectiveness in treatment wetlands (Malecki-Brown and White, 2009; Malecki-Brown et al., 2009). When added to water, alum rapidly dissociates forming aluminum ions that are immediately hydrated (Cooke et al., 1993), and an insoluble, gelatinous poorly crystalline $\mathrm{Al}(\mathrm{OH})_{3}$ floc is formed through several rapid hydrolytic reactions (Ebeling et al., 2003).

Aluminum toxicity in plants is related to the activity of the $\mathrm{Al}^{3+}$ ion, having several different effects on the plant. The most notable result of Al toxicity in upland plants is the inhibition of root elongation and respiration (Schier, 1985; Jarvis and Hatch, 1986) resulting in roots that are thickened, stubby, brittle, and often inefficient in nutrient absorption. There are five possible mechanisms by which Al toxicity affects the cellular function within plants (Taylor, 1989). First, Al may disrupt the structure and function of the plasma membrane which serves as a wall between the cytosol and external environment. A second mechanism of Al toxicity is the inhibition of ATP (Viola et al., 1980) and DNA synthesis as well 
as mitosis. Aluminum also disrupts cellular function by inhibiting cell elongation. The Al binds to the free carboxyls of pectin resulting in cross-linking of the molecules, decreasing the cell wall elasticity, which in turn inhibits root elongation (Klimashevskii and Dedov, 1975; Matsumoto, 2000). Aluminum stress also results in disruption of mineral nutrition. The disruptions could arise from reduction in mycorrhizal association (Entry et al., 1987). Aluminum also interferes with the absorption and transport of $\mathrm{Ca}$ and $\mathrm{Mg}$ in plants, resulting in reduced Ca concentrations in the roots and shoots of Al stressed plants (Baligar et al., 1987; Bennet et al., 1987; Thornton et al., 1987).

Acidification associated with alum dosing is likely, in concert with the increased $\mathrm{Al}$ concentrations, to result in Al toxicity and elevated concentrations in the aquatic plants (Gensemer and Playle, 1999). The aim of the present study was to assess the effects of a continuous low-dosage of alum on plant growth and nutrient uptake of the dominant vegetation types in a polishing wetland system receiving tertiary domestic wastewater. This is, to the authors' knowledge, the first study where the effect of alum dosing in treatment wetlands on wetland vegetation has been studied. The study was conducted in the winter months, the period of time when the $P$ removal rate of the wetland was the lowest (Wang et al., 2006).

\section{Materials and methods}

\subsection{Site description}

A mesocosm study was set up at the City of Orlando's Wastewater Division Easterly Wetlands (OEW) which is a 494 ha polishing (nutrient removal) constructed wetland system located east of Orlando in Florida, USA. The wetlands consist of 16 deep marsh cells dominated by either cattails (Typha domingensis), giant bulrush (Schoenoplectus californicus), or a combination of the two, and two mixed marsh cells dominated by a mixture of submergent and emergent macrophytes including Ceratophyllum demersum, Limnobium spongia, Najas guadalupensis, Nuphar luteum, Nymphaea odorata, Pontederia cordata, Sagittaria lancifolia, and Sagittaria latifolia. The influent total P (TP) concentration from 1988 to 2005 ranged from 0.02 to $3.30 \mathrm{mg} \mathrm{L}^{-1}$ (overall average $0.22 \mathrm{mg} \mathrm{L}^{-1}$ ), and usually the effluent concentrations were much lower than the $0.2 \mathrm{mg} \mathrm{L}^{-1}$ TP discharge permit (Wang et al., 2006). However, effluent TP concentrations have been approaching the permit limit during winters in recent years (Wang et al., 2006). The goal of this specific paper was to examine the effect of alum addition on submerged and emergent plant uptake and growth.

\subsection{Mesocosm establishment}

Eighteen circular (diameter $1.54 \mathrm{~m}$, depth $0.88 \mathrm{~m}$ ) polyethylene mesocosms were established in June 2004 utilizing a randomized block design. The setup included triplicate experimental and control mesocosms planted with the three dominant vegetation types found within the OEW, i.e. either T. domingensis, S. californicus or submergent aquatic vegetation (SAV). Each mesocosm contained a polyvinyl chloride drain which permitted control of water levels to within $\pm 3 \mathrm{~cm}$. The water flowing through the mesocosms originated from the outflow of cell 15 of the OEW (Wang et al., 2006), pumped to a head tank and distributed via gravity to each mesocosm at a rate of $370 \mathrm{~L} \mathrm{~d}^{-1}$. This provided a hydraulic loading rate of $19.8 \mathrm{~cm} \mathrm{~d}^{-1}$, and a retention time of approximately $2.7 \mathrm{~d}$ at a water depth of $53 \mathrm{~cm}$.

Approximately $0.3 \mathrm{~m}$ of homogenized soil from a dredged spoil pile with a mixture of material removed from some of the OEW cells was added to each mesocosm, and the mesocosms were planted on June 30,2004 , to begin a 5 month grow-in (stabiliza- tion) period. All vegetation was collected from the OEW. The six SAV mesocosms were established with $N$. guadalupensis at a density of $2.18 \mathrm{~kg}$ wet weight (WW) $\mathrm{m}^{-2}$. The Typha and Schoenoplectus mesocosms were stocked with 15 whole plants per mesocosm, averaging $1.88 \mathrm{~kg} \mathrm{WW} \mathrm{m}^{-2}$ for Typha and $1.04 \mathrm{~kg} \mathrm{WW} \mathrm{m}^{-2}$ for Schoenoplectus. The leaves of the Typha and Schoenoplectus plants were cut to a length of $79 \mathrm{~cm}$ to begin the grow-in period with uniform plants. A $53 \mathrm{~cm}$ water column was maintained in the SAV mesocosms throughout the entire grow-in, while in the emergent mesocosms, a $28 \mathrm{~cm}$ water column was maintained for the first month in order to allow the plants to establish before raising the water column to $53 \mathrm{~cm}$ for the remainder of the study. After the 5 -month grow-in period (ending December 1, 2004), liquid alum $\left(4.3 \%\right.$ as $\left.\mathrm{Al}^{3+}\right)$ was pumped from a head tank via timer-controlled peristaltic pumps to the triplicate treatment mesocosms through black polyethylene tubing at a rate of $0.91 \mathrm{~g} \mathrm{Al} \mathrm{m}^{-2} \mathrm{~d}^{-1}$ for 3 months resulting in a total addition of $68 \mathrm{~g} \mathrm{Al} \mathrm{m}^{-2}$ while no alum was added to the triplicate control mesocosms for each plant type. This loading rate was found to be sufficient in a previously conducted static core experiment (Malecki-Brown et al., 2007).

\subsection{Water quality}

Temperature, $\mathrm{pH}$, conductivity and dissolved oxygen (DO) in the water were analyzed on-site at mid-morning using a handheld meter (YSI 85, YSI Inc., Yellow Springs, OK, USA). Water samples were collected from each mesocosm 14 times during the grow-in period, then twice weekly for the first month of Al dosing, and weekly for the remainder of the experiment. Water samples were filtered $(0.45 \mu \mathrm{m})$ and analyzed for the different forms of $\mathrm{N}$ and $\mathrm{P}$ as well as dissolved organic C (DOC) and Al. For details about methods see Malecki-Brown et al. (2009).

\subsection{Plant growth and biomass}

Plant aboveground biomass was determined from one $25 \mathrm{~cm} \times 25 \mathrm{~cm}$ quadrant harvested from each mesocosm upon initiation and completion of the Al dosing. Emergent species were clipped at the soil surface while all SAV falling within the quadrant, throughout the water column was collected. All plants were rinsed thoroughly with tap and then distilled water, all visible algae or epiphytes wiped off, and then placed in paper bags and dried at $40{ }^{\circ} \mathrm{C}$ until constant weight was reached.

Green stem counts were taken in the Typha and Schoenoplectus mesocosms every 2 wk over the course of the Al dosing period. The rate of aboveground production of Typha and Schoenoplectus was estimated by measuring shoot or leaf increments over time. In each mesocosm, triplicate newly emerged shoots were tagged loosely around the base for identification purposes. On each subsequent sampling date the individual Typha leaves were tagged and labeled as they emerged. Typha leaf and Schoenoplectus shoot lengths were measured from the soil surface to the most distal portion of the leaf or shoot weekly during the 3-month experiment and biweekly thereafter until all tagged plants were dead (within $46 \mathrm{wk}$ ). A nonlinear regression curve of leaf length to dry weight biomass was established for both Typha and Schoenoplectus by collecting thirty Schoenoplectus shoots of various sizes from cell $1\left(R^{2}=0.95\right)$, and twelve Typha plants (69 leaves) from cell 10 within the OEW $\left(R^{2}=0.93\right)$. Aboveground production was then calculated by multiplying the total leaf growth during the life span of the plants with the number of shoots or stems in the mesocosms. The P and $\mathrm{N}$ uptake associated with growth was calculated by multiplying the aboveground production with the mean $\mathrm{P}$ and $\mathrm{N}$ concentrations in the tissues. The growth in the SAV mesocosms was not determined. For this short-term exposure to alum, it was hypothesized 
that the aboveground biomass would be affected and therefore, the belowground biomass was not monitored.

\subsection{Tissue nutrient concentrations}

Oven-dried plant material was ground in a Wiley mill. Sub-samples were combusted at $550{ }^{\circ} \mathrm{C}$ for $4 \mathrm{~h}$ in a muffle furnace and the ash dissolved in $6 \mathrm{M} \mathrm{HCl}$ on a hot plate (Andersen, 1976). Total $\mathrm{P}$ was analyzed using an USEPA (1993) automated ascorbic acid method (Method 365.4). Total Al, $\mathrm{Ca}, \mathrm{Mg}, \mathrm{Fe}, \mathrm{Mn}$ and $\mathrm{Cu}$ were analyzed by inductively coupled plasma spectrometry (Vista MPX CCD, Varian, Inc., Walnut Creek, CA; Method 200.7, USEPA, 1993). Plant total $C$ and total $N$ concentrations were analyzed by an Elemental Combustion ECS 4010 CHNS-O Analyzer (Costech Analytical Technologies, Inc., Valencia, CA).

\subsection{Statistical analysis}

Data were tested for normality by the Kolmogorov-Smirnov test (Minitab 13.32, 2000) and for homogeneity of variances by Levene's test using Statgraphics XV centurion version 15.1.02 (StatPoint, Inc., USA). The effects of alum application and differences between the different types of vegetation were tested by ANOVA using Type III sum of squares and the General Linear Model procedure of the Statgraphics software. Posthoc comparisons of means were performed using Tukey HSD procedure at the 0.05 significance level. When necessary, data were log or square root-transformed to approximate normality, but for clarity all data are presented as untransformed.

\section{Results}

\subsection{Water quality}

A detailed description of the influent as well as the water quality in the mesocosms throughout the study has been previously presented by Malecki-Brown et al. (2009). Water quality measures were taken weekly. In brief, the overall average water temperature was $18.8 \pm 4.0^{\circ} \mathrm{C}$ and the conductivity averaged $480 \pm 110 \mu \mathrm{S} \mathrm{cm}^{-1}$ during the study. The DO concentrations were slightly higher in the SAV mesocosms, particularly in the mesocosms dosed with alum (Fig. 1A). The water column $\mathrm{pH}$ of the $\mathrm{Al}$ treated mesocoms were consistently lower than in the controls for all type of plants (Fig. 1B) and extremes were $\mathrm{pH}=5.41$ (low) and $\mathrm{pH}=9.91$ (high). For all three plant types, the Al treated mesocosms had significantly lower concentrations of both particulate and dissolved $\mathrm{P}$ forms (Fig. 1C), whereas the different forms of $\mathrm{N}$ had little effect by treatment (Fig. 1D). The concentrations of inorganic $\mathrm{N}$ forms were very low $\left(\mathrm{NH}_{4}-\mathrm{N}<0.05 \mathrm{mg} \mathrm{L}^{-1}\right.$ and $\mathrm{NO}_{3}-\mathrm{N}$ below the method detection limit of $<0.01 \mathrm{mg} \mathrm{L}^{-1}$ ). Hence the main form of $\mathrm{N}$ in the water was dissolved organic $\mathrm{N}$. The soluble $\mathrm{Al}^{3+}$ concentration of the water was below the practical quantitative limit of $0.02 \mathrm{mg} \mathrm{L}^{-1}$.

\subsection{Plant biomass and growth}

Overall there was a significant difference between the harvested biomass of the different vegetation types in the mesocosms, and the biomass developed differently during the period of alum application (Fig. 2 and Supplemental material (SM), Table SM-1). The SAV biomass decreased during the experiment, the biomass of Schoenoplectus increased, while the Typha biomass was identical at the start and the end of alum application (Fig. 2). At the end of the alum dosing, Hydrilla constituted $30-50 \%$ of the biomass harvested in the SAV mesocosms, the remaining biomass being largely Najas.
The growth of the emergent macrophytes during the study was also not affected by the alum application. The leaf elongation rates and the consequent dry matter production differed between Schoenoplectus and Typha with Typha up to four times greater while Schoenoplectus had shoot density values up to nearly six times higher than for Typha (Table 1). However, these differences were caused by the different plant morphology and growth characteristics of the two species, and actually the growth resulted in identical area based aboveground biomass production rates during the experiment (Table 1). There was no significant difference in Typha leaf and Schoenoplectus shoot longevity, averaging slightly over $27 \mathrm{wk}$ from emergence to senescence. Unfortunately, we were not able to monitor growth parameters of the SAV during the study, and have measures at experimental initiation and conclusion for production of biomass.

\subsection{Tissue nutrient concentration}

Most mineral and nutrient concentrations of the plant tissues differed significantly between the vegetation types, and for many parameters, a significant difference between concentrations at initial (at the initiation of the alum dosing period) and final harvest (at the conclusion of the 3 month alum dosing period) also were observed, but applying alum did not affect concentrations significantly (Fig. 3, Tables SM-2 and SM-3). The moisture content varied between $83 \%$ and $91 \%$ of the fresh weight and did not differ between species or treatments, but the ash content was significantly higher in the SAV (19\% DW (dry weight)) than in Schoenoplectus (12\% DW) and Typha (13\% DW). The C content was highest in Typha and lowest in SAV, and was significantly higher in the tissues at the final harvest compared to the initial harvest (Fig. 3A). The tissue $\mathrm{N}$ concentrations were significantly higher in the SAV than in the emergents and the concentrations were lower at the final harvest for SAV and Schoenoplectus whereas the concentrations in Typha did not differ between harvest time and mesocosms (Fig. 3B). The concentrations of $\mathrm{P}$ in the plant tissues differed between the vegetation types and the two harvests (Fig. $3 C$ ). The effects of harvest time differed between the vegetation types as the $P$ concentrations in SAV were two to three times higher at the final harvest whereas the concentrations in the emergents were unaffected or slightly lower. The C/N ratio was lowest in SAV $(20 \pm 1)$ and higher in Typha $(53 \pm 5)$ and Schoenoplectus $(41 \pm 4)$ and in Schoenoplectus, slightly higher at the final harvest than at the initial harvest. The N/P ratios were generally low $(<10)$ and significantly lower in SAV and Schoenoplectus at the final harvest than at the start of the experiment both in control and alum-treated mesocosms (Fig. 3D). Hence, alum application did not affect the N/P-ratio. The concentrations of $\mathrm{Ca}$ and $\mathrm{Mg}$ differed significantly between vegetation types and were generally higher in SAV than in the emergent treatments. The concentrations were higher or at the same level at the final harvest compared to the initial harvest in SAV, whereas for the emergents the concentrations were lowest at the final harvest (Fig. $3 \mathrm{E}$ and F). Iron concentrations were generally highest in the SAV, particularly at the final harvest (Fig. 3G; Table SM-3). The concentrations of $\mathrm{Al}$ in the plant tissues on the other hand, were significantly affected by alum application. The concentrations of $\mathrm{Al}$ in the SAV were 50 times higher in alum dosed mesocosms compared to the controls (which received no alum), but the effects on Al concentrations in Schoenoplectus and Typha were much less, only a factor of two and four, respectively (Fig. 3H).

\subsection{Plant nutrient uptake}

The uptake of $\mathrm{P}$ by the emergent plants during the 3 month experimental period ranged between 0.23 and $0.55 \mathrm{~g} \mathrm{~m}^{-2}$, and the uptake did not differ between the two species and was not af- 

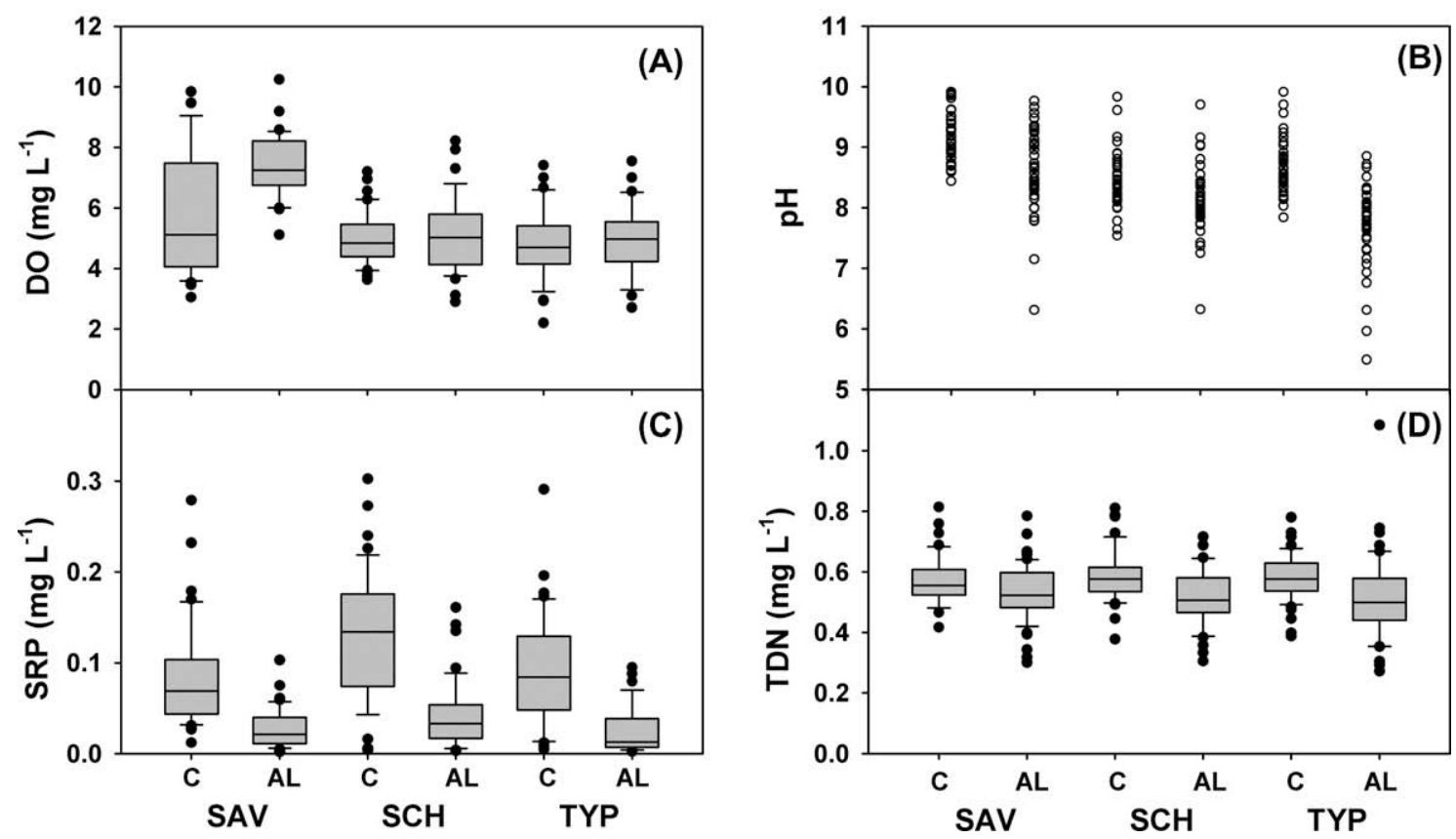

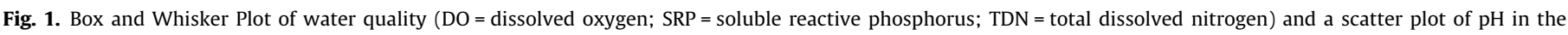

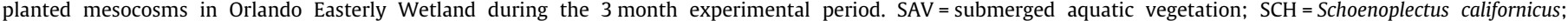

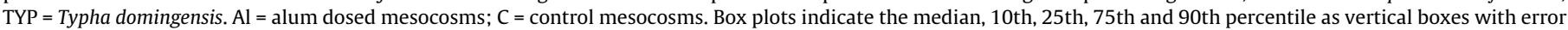
bars.

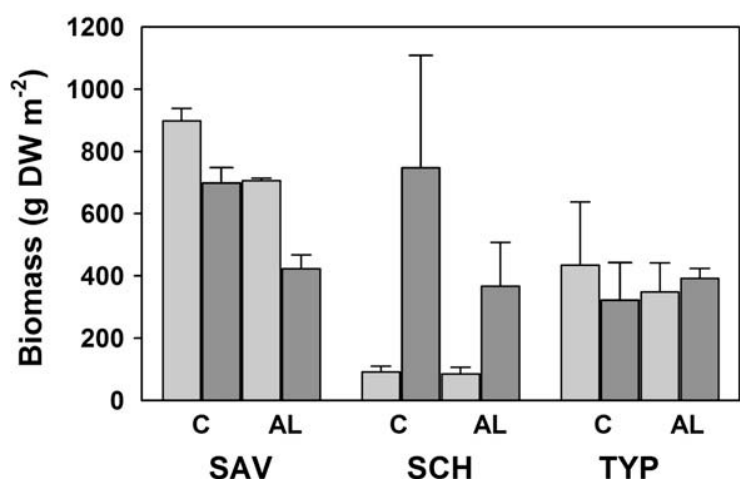

Fig. 2. Average ( $\pm 1 \mathrm{SE}, n=3$ ) biomass of submerged aquatic vegetation (SAV) Schoenoplectus californicus (SCH) and Typha domingensis (TYP) in Orlando Easterly Wetland mesocosms dosed with alum (Al) and controls (C) at the initiation (light gray columns) and at the end (dark gray columns) of the 3 months alum dosing. For statistics, see Table SM-1.

fected by alum treatment (Table 2). The amount of P incorporated into the produced plant biomass constituted between $5.6 \%$ and $13.6 \%$ of the wastewater P load. For N, the uptake ranged between 1.4 and $2.7 \mathrm{~g} \mathrm{~m}^{-2}$, and again there was no difference between species or alum treatment. The amount of $\mathrm{N}$ in tissue constituted between $13 \%$ and $24 \%$ of the wastewater $\mathrm{N}$ load (Table 2 ).

\section{Discussion}

Nutrient removal in treatment wetlands often declines during the winter months due to reduced microbial activity and plant senescence, but application of low doses of alum can significantly improve the treatment efficiencies for soluble reactive P (SRP). The controls (no alum) reduced $44 \%$ of the influent SRP while the treatment (alum added) reduced $66 \%$ of the influent SRP (Malecki-Brown and White, 2009). The application of alum, however, in- creases the exposure of the plants in the wetland to $\mathrm{Al}$, and the potential alum-induced decrease in water $\mathrm{pH}$ may increase the phytotoxic effects of Al. This study showed that alum dosing resulted in slightly lower water $\mathrm{pH}(0.4-0.8 \mathrm{pH}$ units), lower concentrations of $\mathrm{P}$ and organic forms of $\mathrm{N}$, more clear water and, in SAV mesocosms, higher levels of DO. The biomass of the different types of vegetation differed between both vegetation types and over time, but none of the variation could be ascribed to the alum dosing. At the end of the study, the biomass in the SAV mesocosms treated with alum was lower than the biomass of the SAV growing in the control mesocosms, whereas the biomass of the emergents either increased (Schoenoplectus) or was unchanged (Typha). This suggests that alum may have negatively impacted the SAV due to its life form (submerged) while emergent plant biomass remained relatively unaffected during the short-term. Submerged aquatic vegetation adsorbs the majority of nutrients and metals directly from the water column into the shoots, while emergent plants tend to obtain them from the soil porewater (Barko et al., 1991; Madsen and Cedergreen, 2002). The reduced biomass in the alum-treated SAV mesocosms may have resulted from lower nutrient availability or possibly Al toxicity; however our experiment was not designed to elucidate the mechanism. There were also no significant differences in winter growth characteristics between the two emergent macrophytes in the control and alum-treated mesocosms. The average higher biomass in the Typha mesocosms during the dosing period may explain why, with the exception of DOC and TKN, both the alum and control mesocosms planted with Typha always performed better for nutrient removal than the Schoenoplectus (Malecki-Brown et al., 2009).

Alum treatment did also not affect the nutrient and mineral composition of the macrophytes, except the concentrations of $\mathrm{Al}$ in the plants, which as expected were significantly elevated in the alum-treated mesocosms, and most so in the SAV, which had over 50 times more Al than the SAV growing in the control tanks. There was no difference in tissue $P$ concentrations of any of the treatment vs. control macrophytes. This was a surprising result considering the significant sequestration of P from the water col- 
Table 1

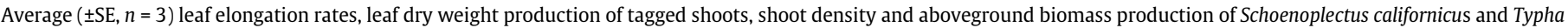
domingensis during the 3 months experimental period in alum dosed mesocosms and controls. Results of two-way ANOVA (F-ratios) are indicated.

\begin{tabular}{|c|c|c|c|c|c|}
\hline Plant species & Treatment & Leaf elongation rate $\left(\mathrm{cm} \mathrm{d}^{-1}\right)$ & Leaf growth (mg leaf $\mathrm{DW} \mathrm{d}^{-1}$ ) & Shoot density $\left(\# \mathrm{~m}^{-2}\right)$ & $\begin{array}{l}\text { Biomass production } \\
\left(\mathrm{g} \mathrm{DW} \mathrm{m}^{-2}\right)\end{array}$ \\
\hline Schoenoplectus & $\begin{array}{l}\text { Alum } \\
\text { Control }\end{array}$ & $\begin{array}{l}1.9 \pm 0.1 \\
1.9 \pm 0.2\end{array}$ & $\begin{array}{l}91 \pm 8 \\
94 \pm 15\end{array}$ & $\begin{array}{l}43 \pm 7 \\
85 \pm 30\end{array}$ & $\begin{array}{l}149 \pm 23 \\
350 \pm 199\end{array}$ \\
\hline Typha & $\begin{array}{l}\text { Alum } \\
\text { Control }\end{array}$ & $\begin{array}{l}8.8 \pm 0.9 \\
8.3 \pm 1.4\end{array}$ & $\begin{array}{l}145 \pm 21 \\
126 \pm 30\end{array}$ & $\begin{array}{l}15 \pm 2 \\
15 \pm 1\end{array}$ & $\begin{array}{l}266 \pm 40 \\
252 \pm 44\end{array}$ \\
\hline $\begin{array}{l}\text { ANOVA } \\
\text { Main effects }\end{array}$ & $\begin{array}{l}\text { Plant species } \\
\text { Treatment }\end{array}$ & $\begin{array}{l}59.03^{* * *} \\
0.09\end{array}$ & $\begin{array}{l}5.25^{*} \\
0.18\end{array}$ & $\begin{array}{r}10.06^{*} \\
0.22\end{array}$ & $\begin{array}{l}0.01 \\
0.79\end{array}$ \\
\hline Interaction & $\begin{array}{l}\text { Plant } \\
\text { species } \times \text { treatment }\end{array}$ & 0.09 & 0.38 & 0.38 & 1.05 \\
\hline
\end{tabular}

${ }^{*} P<0.05$.

**** $P<0.001$.
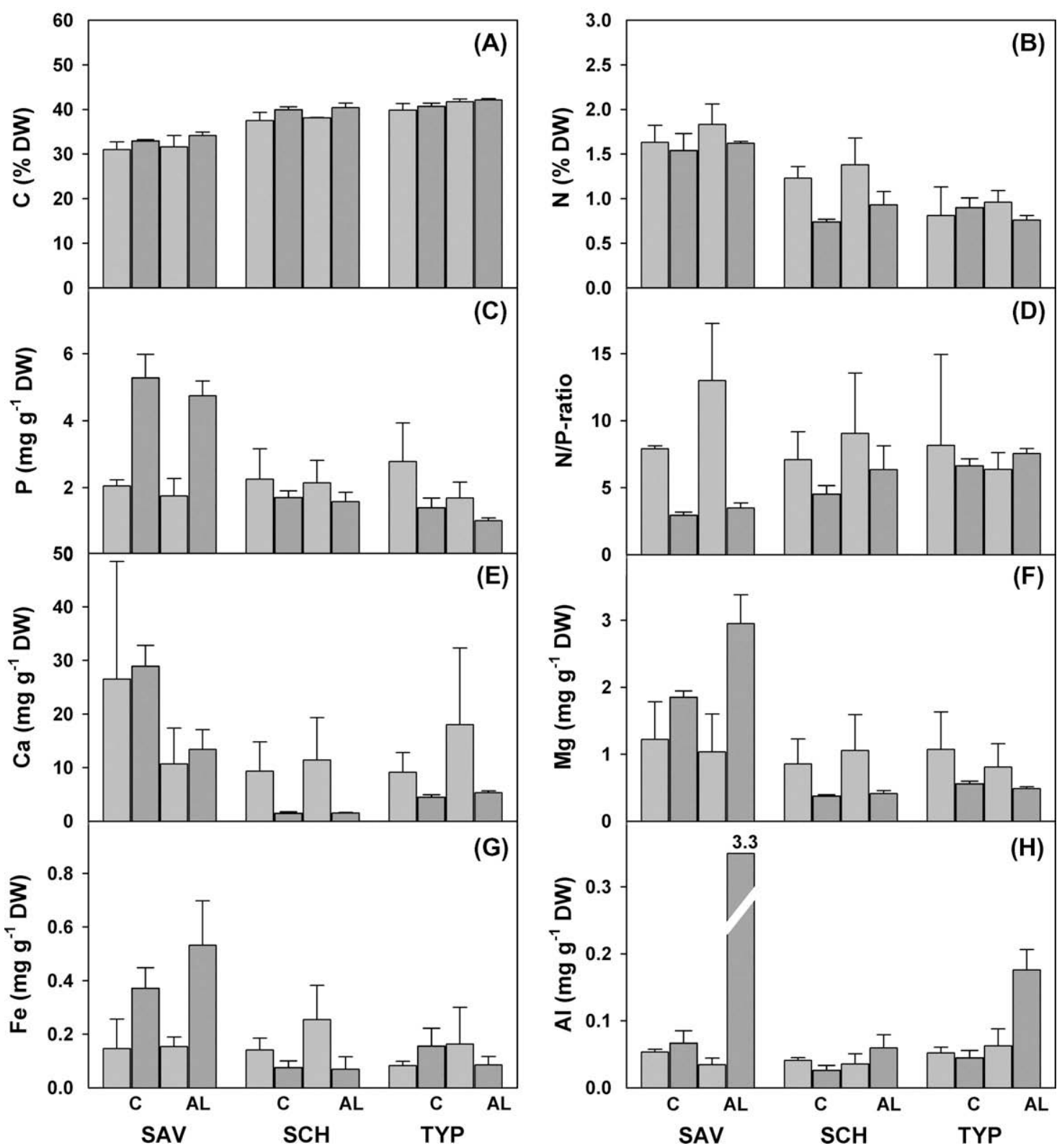

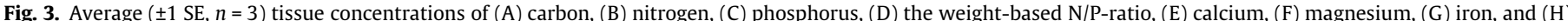

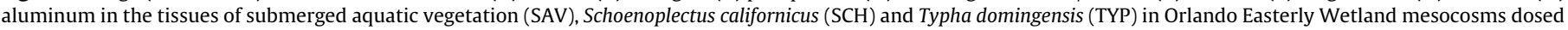

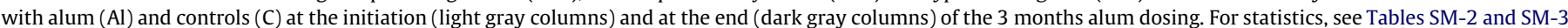


Table 2

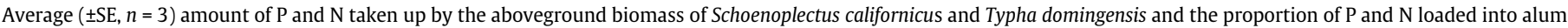
dosed mesocosms and controls during the 3 months experimental period. Results of two-way ANOVA (F-ratios) are indicated.

\begin{tabular}{|c|c|c|c|c|c|}
\hline \multirow[t]{2}{*}{ Plant species } & \multirow[t]{2}{*}{ Treatment } & \multicolumn{2}{|l|}{ P-uptake } & \multicolumn{2}{|l|}{ N-uptake } \\
\hline & & $\left(\mathrm{g} \mathrm{m}^{-2}\right)$ & (\% of loading) & $\left(\mathrm{g} \mathrm{m}^{-2}\right)$ & (\% of loading) \\
\hline \multirow{2}{*}{ Schoenoplectus } & Alum & $0.23 \pm 0.02$ & $5.6 \pm 0.4$ & $1.4 \pm 0.49$ & $13 \pm 4$ \\
\hline & Control & $0.55 \pm 0.30$ & $13.6 \pm 7.4$ & $2.7 \pm 1.5$ & $24 \pm 14$ \\
\hline \multirow[t]{2}{*}{ Typha } & Alum & $0.27 \pm 0.06$ & $6.8 \pm 1.5$ & $2.1 \pm 0.5$ & $19 \pm 4$ \\
\hline & Control & $0.36 \pm 0.10$ & $9.1 \pm 2.6$ & $2.3 \pm 0.6$ & $22 \pm 5$ \\
\hline \multicolumn{6}{|l|}{ ANOVA } \\
\hline \multirow[t]{2}{*}{ Main effects } & A: plant species & 0.17 & & 0.03 & \\
\hline & $\mathrm{B}$ : treatment & 1.64 & & 0.74 & \\
\hline Interaction & $A \times B$ & 0.52 & & 0.30 & \\
\hline
\end{tabular}

umn by the alum macro-floc which could have limited P availability to the SAV. We hypothesize that in the short-term, alum is not expected to affect $P$ nutrition of rooted aquatic macrophytes because they are able to access $P$ from the soil porewater (Carignan and Kalff, 1979; Welch and Schrieve, 1994). However, the floc will become buried over time as organic matter accretion occurs in the wetland (DeLaune and Pezechki, 2003). In many aquatic and wetland systems, the majority of available $P$ is concentrated within the surface $(0-10 \mathrm{~cm})$ interval (Grace et al., 2008; Malecki et al., 2004). Repeated applications of alum from year to year may potentially immobilize plant available $P$ in the soil porewater as the alum is buried among the accreting organic matter from year to year.

The N/P ratios were generally low and significantly lower in SAV and Schoenoplectus at the final harvest than at the start of the experiment both in control and alum-treated mesocosms. Koerselman and Meuleman (1996) suggested that tissue N/P ratios $<14$ indicate $\mathrm{N}$ limitation, whereas tissue $\mathrm{N} / \mathrm{P}$ ratios $>16$ indicate $\mathrm{P}$ limitation. Accordingly, in the present study the macrophytes were generally limited by $\mathrm{N}$ irrespectively on $\mathrm{P}$ level in the water and alum treatment. The alum treatment did significantly lower water column total dissolved $\mathrm{N}$ and TKN because of its ability to bind organically-bound $\mathrm{N}$ (Jansen et al., 2002), but inorganic $\mathrm{N}$ forms were not impacted by alum application.

Uptake of nutrients by plants is one of the mechanisms removing nutrients in treatment wetlands (Brix, 1994). In this study the amount of $\mathrm{N}$ and $\mathrm{P}$ incorporated into the newly produced aboveground biomass of the emergent macrophytes constituted up to $13.6 \%$ and $24 \%$, respectively, of the $\mathrm{P}$ and $\mathrm{N}$ loaded into the systems with the wastewater.

Management implications from this study are dependent upon what the effluent water quality requirements are for the treatment wetland. For example, this particular wetland has outflow requirements for $\mathrm{pH}, \mathrm{N}$ and $\mathrm{P}$ as well as particulates. Therefore, addition of alum in close proximity to the outflow could pose a problem for meeting discharge criteria. A settling basin may be required to collect the alum floc since any floc that leaves the wetland would affect both the particulate and TP water quality measures. In addition, the settling basin would need to be emptied from time to time. Since alum addition may be used as a retrofit, there may be no space available for a settling basin and therefore, we suggest adding the alum in areas of emergent plants as opposed to submerged plants.

\section{Conclusions}

During the winter months, wetlands in the southern United States may become less effective at removing $\mathrm{P}$ as plants senesce and microbial activity slows. Permits require effluents from treatment wetlands to meet specific discharge criteria regardless of sea- son. Application of alum to the wetland may provide an effective tool to maintain discharge concentrations within permitted values. We were not able to document any statistically significant negative impacts of alum dosing on growth and mineral composition of the emergent macrophytes $T$. domingensis and S. californicus, except for the tissue concentrations of $\mathrm{Al}$, which were elevated by a factor of 2 and 4, respectively. However, submerged aquatic macrophytes were significantly more affected with Al tissue concentrations 50 -fold higher. In the long term, the alum floc becomes buried among the accreting organic matter in the soil profile and may influence nutrient availability in the future. For management purposes, we suggest therefore, that the use of alum should be restricted to treatment wetland areas dominated by emergent vegetation. The long term efficacy of alum $P$ sequestration as well as its long term impact on aquatic macrophytes in treatment wetlands needs further investigation.

\section{Acknowledgments}

This research was funded by the City of Orlando and supported by the PADI Foundation and an alumni fellowship from the University of Florida. Additional travel and salary support was provided by the John P. Laborde Endowed Chair for Sea Grant Research and Technology Transfer Program. A special thanks to Mark Sees and the City of Orlando for project coordination. Maverick Leblanc and Brett Marks, Louisiana State University, are acknowledged for laboratory assistance. Sue (Simon) Lindstrom, Chakesha Martin, Erin (Bostic) Corstanje, and Dr. Eric A. Brown are thanked for their assistance in mesocosm establishment and sampling.

\section{Appendix A. Supplementary material}

Supplementary data associated with this article can be found, in the online version, at doi:10.1016/j.chemosphere.2010.02.006.

\section{References}

Andersen, J.M., 1976. An ignition method for determination of total phosphorus in lake sediments. Water Res. 10, 329-331.

Baligar, V.C., Wright, R.J., Kinraide, T.B., Foy, C.D., Elgin Jr., J.H., 1987. Aluminium effects on growth, mineral uptake and efficiency ratios in red clover cultivars. Agron. J. 79, 1038-1044.

Barko, J.W., Gunnison, D., Carpenter, S.R., 1991. Sediment interactions with submersed macrophyte growth and community dynamics. Aquat. Bot. 41, 4165.

Bennet, R.J., Breen, C.M., Fey, M.V., 1987. The effects of aluminum on root cap function and root development in Zea mays L. Environ. Exp. Bot. 27, 91-104.

Berkowitz, J., Anderson, M.A., Amrhein, C., 2006. Influence of aging on phosphorus sorption to alum floc in lake water. Water Res. 40, 911-916.

Brix, H., 1994. Functions of macrophytes in constructed wetlands. Water Sci. Technol. 29 (4), 71-78.

Brix, H., 1997. Do macrophytes play a role in constructed treatment wetlands? Water Sci. Technol. 35 (5), 11-17. 
Carignan, R., Kalff, J., 1979. Quantification of the sediment phosphorus available to aquatic macrophytes. J. Fish. Res. Board Can. 36, 1002-1005.

Conkle, J.L., White, J.R., Metcalfe, C.D., 2008. Reduction of pharmaceutically active compounds by a lagoon wetland wastewater treatment system in Southeast Louisiana. Chemosphere 73, 1741-1748.

Cooke, G.D., Welch, E.B., Peterson, S.A., Newroth, P.R., 1993. Phosphorus Activation and Sediment Oxidation. Restoration and Management of Lakes and Reservoirs. Lewis Publishers, Boca Raton, Florida, USA, pp. 161-209.

DeLaune, R.D., Pezechki, S.R., 2003. The role of soil organic carbon in maintaining surface elevation in rapidly subsiding US Gulf of Mexico coastal marshes. Water Air Soil Pollut. 3, 167-179.

Ebeling, J.M., Sibrell, P.L., Ogden, S.R., Summerfelt, S.T., 2003. Evaluation of chemical coagulation-flocculation aids for the removal of suspended solids and phosphorus from intensive recirculating aquaculture effluent discharge. Aquacult. Eng. 29, 23-42.

Entry, J.A., Cromack Jr., K.G., Stafford, S.G., 1987. The effect of pH and aluminum concentration on ectomycorrhizal formation in Abies balsamea. Can. J. Forest Res. 17, 865-871.

Gensemer, R.W., Playle, R.C., 1999. The bioavailability and toxicity of aluminum in aquatic environments. Crit. Rev. Environ. Sci. Technol. 29, 315-450.

Grace, K.A., Dierberg, F.E., DeBusk, T.A., White, J.R., 2008. Phosphorus uptake by Typha leaf litter as affected by oxygen availability. Wetlands 28, 817-826.

Jansen, S., Broadley, M.R., Robbrecht, E., Smets, E., 2002. Aluminum hyperaccumulation in angiosperms: a review of its phylogenic significance. Bot. Rev. 68, 235-269.

Jarvis, S.C., Hatch, D.J., 1986. The effects of low concentrations of aluminum on the growth and uptake of nitrate-N by white clover. Plant Soil 95, 43-55.

Klimashevskii, E.L., Dedov, V.M., 1975. Localization of growth inhibiting action of aluminum ions in elongating cell walls. Fiziol. Rast. 22, 1183-1190.

Koerselman, W., Meuleman, A.-F.M., 1996. The vegetation N:P ratio: a new tool to detect the nature of nutrient limitation. J. Appl. Ecol. 33, 1441-1450.

Madsen, T.V., Cedergreen, N., 2002. Sources of nutrients to rooted submerged macrophytes growing in a nutrient-rich stream. Freshwater Biol. 47, 283-291.

Malecki, L.M., White, J.R., Reddy, K.R., 2004. Nitrogen and phosphorus flux rates from sediment in the Lower St. Johns River estuary. J. Environ. Qual. 33, 15451555.
Malecki-Brown, L.M., White, J.R., 2009. Effect of aluminum-containing amendments on phosphorus sequestration of wastewater treatment wetland soil. Soil Sci. Soc. Am. J. 73, 852-861.

Malecki-Brown, L.M., White, J.R., Reddy, K.R., 2007. Soil biogeochemical characteristics influenced by alum application in a municipal wastewater treatment wetland. J. Environ. Qual. 36, 1904-1913.

Malecki-Brown, L.M., White, J.R., Sees, M., 2009. Alum application to improve water quality in a municipal wastewater treatment wetland. J. Environ. Qual. 38, 814821.

Matsumoto, H., 2000. Cell biology of aluminum toxicity and tolerance in higher plants. Int. Rev. Cytol. 200, 1-46.

Schier, G.A., 1985. Response of red spruce and balsam fir seedlings to aluminum toxicity in nutrient solutions. Can. J. Forest Res. 15, 29-33.

Taylor, G.J., 1989. Aluminum toxicity and tolerance in plants. In: Adriano, D.C. Johnson, A.H. (Eds.), Advances in Environmental Science. Acidic Precipitation, vol. 2. Springer-Verlag, New York, NY, pp. 327-361.

Thornton, F.C., Schaedle, M., Raynal, D.J., 1987. Effects of aluminum on red spruce seedlings in solution culture. Environ. Exp. Bot. 27, 489-498.

USEPA, 1993. Methods of Chemical Analysis of Water and Wastes. Environ. Monit. Support Laboratory, Cincinnati, Ohio, USA

Viola, R.E., Morrison, J.F., Cleland, W.W., 1980. Interactions of metal(III)-adenosine 5'-triposphate complexes with yeast hexokinase. Biochemistry 19, 3131-3137.

Wang, H.G., Jawitz, J.W., White, J.R., Martinez, C.J., Sees, M.D., 2006. Rejuvenating the largest municipal treatment wetland in Florida. Ecol. Eng. 26, 132-146.

Welch, E.B., Schrieve, G.D., 1994. Alum treatment effectiveness and longevity in shallow lakes. Hydrobiologia 276, 423-431.

White, J.R., Reddy, K.K., 1999. Influence of nitrate and phosphorus loading on denitrifying enzyme activity in Everglades wetland soils. Soil Sci. Soc. Am. J. 63, 1945-1954.

White, J.R., Reddy, K.R., 2000. Influence of phosphorus loading on organic nitrogen mineralization of everglades soils. Soil Sci. Soc. Am. J. 64, 1525-1534.

White, J.R., Gardner, L.M., Sees, M., Corstanje, R., 2008. The short-term effects of prescribed burning on biomass removal and the release of nitrogen and phosphorus in a treatment wetland. J. Environ. Qual. 37, 2386-2391. 